\title{
Interview
}

\section{TBLT meets CMC: Using Virtual Worlds (VWs) in the language learning and teaching. An interview with Dr. Randall Sadler}

\author{
Ha Ram Kim \\ University of Illinois at Urbana-Champaign, USA
}

Text received 14 May, 2015; final version 10 June 2015

DOI: http://dx.doi.org/10.5565/rev/jtl3.632

Dr. Randall Sadler is a Professor in the Department of Linguistics, University of Illinois at Urbana-Champaign (USA). The primary focus of Dr. Sadler's current research is the role of Computer-Mediated Communication and Virtual Worlds (VWs) in the language learning/teaching process. Virtual Worlds are 3-D online environments inhabited by 'people' in the form of avatars. There are a large number of virtual worlds, ranging from true game environments--often referred to as Massively-Multiplayer Online Games (MMOGs)--to VWs that exist primarily as social environments. These include Second Life, Active Worlds, Club Penguin, There, and many more. The primary focus of his interest is Second Life (SL) as there are a wide variety of education applications in SL that are constantly evolving.

Dr. Randall Sadler es profesor en el Departamento de Lingüística de la Universidad de Illinois en Urbana-Champaign (EE.UU.). El enfoque principal de su investigación es el papel de la Comunicación Mediada por el Ordenador (CMO) y los Mundos Virtuales (MV) en el proceso de enseñanza/aprendizaje de lenguas. Mundos virtuales son entornos en línea 3-D habitadas por 'personas' en la forma de avatares. Hay un gran número de mundos virtuales, que van desde entornos de juego muy reales - a menudo referido como Juegos en línea con Multijugadores en Masivo (MMOG en inglés) - hasta MVs que existen principalmente como entornos sociales. Estos incluyen Second Life, Active Worlds, Club Penguin, There, y muchos más. El enfoque principal de su interés es en Second Life (SL), ya que hay una amplia variedad de aplicaciones educativas en SL que están en constante evolución.

Dr. Randall Sadler és professor al Departament de Lingüística de la Universitat d'Illinois a Urbana-Champaign (EUA). L'enfocament principal de la seva recerca és el paper de la Comunicació Mediada per l'Ordinador (CMO) i els Mons Virtuals (MV) en el procés d'ensenyament/aprenentatge de llengües. Mons virtuals són entorns en línia 3-D habitades per 'persones' amb la forma de avatars. Hi ha un gran nombre de mons virtuals, que van des entorns de joc molt reals - sovint referits com a Jocs en línia amb Multijugadors en Massiu (MMOG en anglès) - fins MVs que existeixen principalment com a entorns socials. Aquests inclouen Second Life, Active Worlds, Club Penguin, There, i molts més. L'enfocament principal del seu interès és a Second Life (SL), ja que hi ha una àmplia possibilitat d'aplicacions educatives a SL que estan en constant evolució.

INTERVIEWER: There has been a continuous increase in attempts to incorporate more webbased approaches to language learning and teaching in order to increase authentication and collaboration in language learning. In your opinion, what do you think about the current status of CALL in language learning and teaching? 
SADLER: First, in terms of what I think of the current status of CALL in language learning and teaching, it's important to differentiate between CALL from other areas like Computer-Mediated Communication. For CALL or Computer-Assisted Language Learning, some people refer to a computer as a "tutor", and for CMC or Computer- Mediated Communication, a computer would be used as a "tool" to communicate with other people. An example of CALL might be - what most people are familiar with -Rosetta Stone. That is one of the programs you can see on the commercials, and you can go to their website to buy the program.

CALL does have a place in language learning and teaching, and I tend to think of it more as a supplemental activity to what is taught in the classroom. For instance, Rosetta Stone claims that it is the easiest way to learn a language but certainly, there has been a recent research that specifically looked at Rosetta Stone and how well it works for language. What they found was that it doesn't. Programs like Rosetta Stone teach everything in L2 (second language), which is not at all a bad idea, but really in some ways, it still has an audio-lingual approach to language learning and teaching. That is not a horrible thing, but it is not the best way to learn and teach a language. CALL used to be huge; If you think about some of the projects we've had such as PLATO, which took place here in the University of Illinois, that was one of the huge early projects with a lot of CALL projects that developed materials for not only for science and history, but also for language learning. One of the advantages of CALL is that you can get an instant feedback, but again, it tends to be very audio-lingual. If you make mistakes, it corrects them right away. It claims to prevent language learners from becoming "fossilized" or "be stuck" in one stage. This is what people used to think and also where CALL comes from. As I mentioned earlier, CALL does have a place in language learning and teaching, especially as a supplement and extra activities. It's just not very 'communicative'.

INTERVIEWER: There has been some debate or concern as to whether a Computer-Mediated Communication approach could actually be used in the classroom -how it could be to the actual classroom context for different groups of people. Your EUROCALL 2008 presentation addressed the topic - what is your opinion on $\mathrm{CMC}$ in the classroom and have your ideas changed or evolved in the last few years?

Bellaterra Journal of Teaching \& Learning Language \& Literature. 8.2 (May-June 2015) ISSN 2013-6196 
SADLER: If CALL uses a computer as a "tutor", Computer-Mediated Communication or CMC uses a computer as a "tool" to help people to communicate with other people. That is the idea behind the $\mathrm{CMC}$ and telecollaboration, which is to collaborate with other people at a long distance. CMC would include emails (using computer to communicate with others), text-chat, instant messaging, message boards, voice or video chat - A lot of times it could be used for business or talking to parents, but language learners are increasingly using it as well. So, if you are doing telecollaboration, you are probably doing some form of CMC. The key focus of telecollaboration tends to be a cultural exchange, which is an European-created idea, but they (telecollaboration and $\mathrm{CMC}$ ) are definitely associated together.

I first taught a course that I teach here every year at the U of I, Computer Mediated Communication for language learners, about 12 years ago. At that time, when I asked people (there were about 30 people in my class) what MSN, Yahoo messenger or Skype was, those tools were very new. Some people had never used an email before! What has happened since then is that the tools available to people have become much more widespread, much more powerful, much easier to use and much more available to anyone as long as they have the Internet connection. In the US, we are kind of falling behind, but in countries like Korea, access to the Internet and speed are enormous. Is it good for the classroom? I'd say, it depends. I remember reading a lot of studies in the past looking at the effects of chat rooms on language learners, and the research study was designed in the way that all the students were in the same room, logged on to the computer, and they were engaged in a chat with a person sitting right next to them. However, what would be the purpose of using chat rooms if you could simply turn your heads and talk to people around you? If any of these tools can be used to accomplish something that we cannot achieve in regular classrooms, I think they make a lot of sense.

The idea behind telecollaboration is similar. You take one group or one class of people and have them collaborate with another group or class; they can simply communicate and exchange ideas, cultures, and many other things. And that's where telecollaboration becomes more valuable and powerful. For instance, if you are teaching a class of students in Korea and students are learning about the English language and American or British culture, you can find another class in the US or UK to collaborate. Making a connection with the class would bring something to the students by literally "opening up the world" to them. 
Also, any students who wish to learn a language like Spanish, they can read newspapers in the language, watch television shows in the language, or engage in discussion boards in the language. The opportunities for interaction in another language is almost limitless, as long as people have access to the Internet, but I think not many people are using such opportunities.

INTERVIEWER: Most of your previous research focused on task-based language learning and teaching with technology, especially with Virtual Worlds. Integrating the VWs to language learning/teaching is considered relatively new to the field. How would you summarize the evolution of using the Virtual Worlds to language learning and teaching?

SADLER: Virtual Worlds (VWs) have not been around all that long, maybe 10 years. Most VWs, and the one that I work with the most is called Second Life - their philosophy is that "here is a space, and let's see what people do with it". For people who are not familiar with VW, VW is a three-dimensional online environment. People have seen examples in games such as World of Warcraft, and that's also a 3-D environment where people can interact with others through their Avatars. A VW, on the other hand, as opposed to multi-online role-playing games like World of Warcraft, in VW what you are doing is typically social activities. In a lot of VWs, there are areas that cover almost everything such as beaches where people are virtually sitting around and chatting, or selling clothes. At the same time, there have been some movements that are geared towards learning and education. As you know, I has two islands in Second Life called EduNation and on those islands, there are people who are teaching languages like Spanish, Thai, English and many others. Some bring existing students into the VWs, because there are islands that use one primary language. There are also islands that use only Japanese or Portuguese. One of the islands, now called Habbo Hotel -each Habbo Hotel does represent a single country. If you "log-in" to the hotel, you will find that people in each room would chat in different languages. For instance, you are interested in learning German, you can find an area in Second Life where most people use German, and have ability to have a real-time interaction using chat rooms or discussion boards with native speakers.

I once did an interview with a guy from Japan who was in his $50 \mathrm{~s}$. He really wanted to have a chance to improve English via Second Life, because he hadn't used English since college. 
So he tried to understand English in text chats at the beginning. Later he became involved in a role-playing community, and he eventually started to type in English, have more opportunities for listening and voice chatting. He had a very difficult time understanding the written text at the beginning, but two and half years later, he was giving us a talk about what he had learned about English in Second Life, all in English. He did not sound like a native speaker, but he was communicating complex ideas very well, all in English! He did not take any classes to learn the language, and everything happened through the interactions in Second Life. He was very motivated to learn, because he wanted to communicate with others about topics he was very passionate about. And a lot of people do that in Second Life. People talk about books together, design clothes together, or even learn to ballroom dance together! People might be dancing with someone and talking with other people, for instance.

INTERVIEWER: There is an increasing popularity or need for web-based (computer-mediated) task learning and teaching - why do you think this is happening? And what are the benefits of computer-mediated communication when compared to traditional classroom teaching and learning?

SADLER: In some cases, people should prefer classroom teaching, because all depends on the purpose of the class and the level of the students. There are some things that function better in a classroom. But if you'd like to design a communication activity for an authentic purpose, language with authentic goals, one of the goals of learning a second language is to be able to talk/communicate in the second language. If you are in a traditional foreign language classroom, if you are lucky, you have one native speaker of the language - usually, your teacher; but in most cases, it is not even the case. But if your goal is to teach students how to communicate in that language as well as the uses of the language, that's where CMC gives you an option. There are a lot of websites that focus on this language exchange (e.g., http://www.mylanguageexchange.com/). In addition to these sites that are designed for one-toone exchange, there are sites that focus more on class-to-class exchange or setting up institutionto-institution connections (e.g, http://uni-collaboration.eu/). It is more ideal and easier to manage, and you can really focus on what you want to do with the school activities. 
I am trying to convince a couple of people that they should set up a CMC exchange between class here, teaching Spanish, with an upcoming graduate who will be teaching in Mexico, to do a class exchange via CMC. It is not like asking students to "fix my grammar," but it would be more like talking about food, clothing, and sports. Compared to the things that are being talked about the most in classroom textbooks, topics could be the same but the communication will be done in a much more authentic way. While traditional textbooks can be quite out-of-date, what students can talk about can be very up-to-date and relevant to their real lives, which becomes more interesting to the students as well.

INTERVIEWER: In order to engage in such CMC activities, do students have to be at certain level in the second/foreign language?

SADLER: Maybe, or maybe not. CMC can be synchronous (e.g. class exchange between the US and Mexico), but it can also be asynchronous (e.g. email exchange or message boards). If you are doing a classical class exchange with a lower level of students, it can be more similar to a traditional classroom. The communication can be put together by both teacher and students, creating one message. If a teacher is clear about the focus, s/he can easily control the class content. For instance, if the topic is sports and teacher wants to have students use future tense, the message that students construct will have future-tense elements related to sports (e.g. "who will play?"). The teacher at other the school or class will interpret the message received from the other side and also help students analyze and understand the message better. And the students would have to compose a message in their second/foreign language to reply back to the original message. In such cases, students can be at a very lower level in terms of proficiency, and teachers' role will be more important.

INTERVIEWER: You are one of the pioneers in using Virtual Worlds as social environments for language teaching and learning. Could you introduce some of the projects you have been working on with respect to the Virtual Worlds (e.g. Second Life)?

SADLER: Let me specifically mention two projects; both of them were done with Melinda Dooly. These were funded by the Spanish government. The first project that we worked together 
on (PADS: http://pagines.uab.cat/pads/en/content/pilot-project-0) involved primary school students in Barcelona, which means these were very young students-- 6 years old in the first year of the project. Then the other group was a group of students in Canada. What we tried to do was to use a VW, specifically Second Life. We built an art gallery in EduNation and first, Melinda was in the classroom in the back of the classroom. Students were sitting on the floor looking at the wall. Projected on the wall was the art gallery. Their teacher was in front of the classroom and what she did was to get them to talk to Snoopy, which was an Avatar controlled by Melinda (Melinda was logged onto the SL as Snoopy). Teacher would say, "Hello, Snoopy. How are you?" and the Avatar would wave. The teacher would first start giving a direction to Snoopy such as "go right" or "go left", and then the students were giving directions to Snoopy. It was like a total physical response (TPR) but in a reverse way as students were telling Snoopy what to do. This was one way to have students engage in the language-in-action. Later, the teacher followed up by asking, "Go to the painting that has this shape and/or color." They took it to the real world as well. For instance, they would use a Google Map and say, "Here's map of the school, and here a map of the museum for a field trip. How would you get to the museum?" The teacher would be giving directions and students would follow a map. This is one way that we used a virtual world for language learning and teaching.

In the following year, what we did was much bigger (PADS: http://padshealtyhabits.pbworks.com/). In the second year of the project, what we did was to work with the same group of students - a year older now - and with a partner group of students in Vienna, Austria (article forthcoming titled "Becoming little scientists: A case study of technologically-enhanced project-based language learning." Accepted for publication in Language Learning \& Technology, 2016). In all of these cases, students were learning English. We worked with teachers in both places (Barcelona and Vienna) to decide what to do, and they decided on the unit called, "healthy habits" which was normally in their curriculum. It was important, because you would not want to do something that is not relevant to what students are actually learning or need to learn.

Melinda and I created two scientists, more specifically two future scientist avatars. We made a series of movies in Second Life first introducing ourselves and then what scientists do (e.g. scientists take notes). These were all shown in 'machinema' (videoclips in which the 'starring roles' are played by avatars), all in English, providing students with a lot of enforcement 
at a level students would normally get in classrooms. Then we would group students in the class and recruit them (e.g. we need your help) to be our little scientist helpers. We introduced them to three 'cases': Smelly Susan, Hungry Helga, and Gameboy Gary, who all had health issues. And we made three interviews for each one of these characters ( 9 minutes per videoclip) for each school. For each school, the students would watch each movie with a couple weeks' period of time. So they could see what was happening to these people over time. For instance, Smelly Susan never took showers. So by the third movie, she had a couple of flies around her body, and interviewers had gas masks around them. In real life, it would be difficult to trap flies around the body, however, in Second Life or virtual movie, you can do everything with regards to animation. You can custom-animate for free.

What was more interesting is that each movie was slightly different for each school so that an information gap was created. For example, in one of the movies, Susan would say, "I never shower" but in other movie, she might explain a 'good' habit, "I eat fruit". That way, each school learned something different and the focus was not only on 'bad' things about the avatars. Later, when students in Spain and Austria communicated together, they had something to ask each other about and important information to share so that they could 'get the whole picture' shared knowledge-building. In each class, they also talked about vocabulary related to healthy habits, and they were also writing about healthy habits.

What we found when we talked to the teachers was that for some of the things we asked the students to do, the teachers at first doubted if students could actually do that (although they were always more than willing to give it a try; we never 'forced' any activities on the teachers). But with all these enforcements provided in the Virtual movies, the teachers were really surprised that their students were producing the language at a greater linguistic complexity than they had thought to be possible. The article that is coming out soon has actual links to these videos. Again, these were very low-level learners and also very young, but clearly they were achieving a lot with the language.

INTERVIEWER: That sounds very interesting! What have been some of the "peaks and valleys" in creating the Virtual Worlds in Second Life? 
SADLER: Let me say, first of all, Second Life is far from being perfect. However, for me one of the peaks of virtual worlds like Second Life is that if somebody has some skills, it allows you to create an environment for your students for things like role-play activities for a very little amount of money, but you can do almost anything. I like building things, so I've made many different places - from a 'Mad Scientist' laboratory, to castles, to classrooms, to pyramids, to lecture halls - anything you'd like to build. Or if you are using a VW to teach vocabulary for students, you can build a market place. You can have one group of students be shopkeepers and one group as the customers, and they can have an interaction.

However, creating virtual worlds in Second Life certainly has been an evolution. When I first started using Second Life, it used to have only text chats. Then, someone developed a technology to include oral chats. In the future, they are planning to use tools to make it more immersive; for instance, with a headgear, people who have access to the Second Life would be more immersed into the virtual reality. Instead of a virtual world only in a screen, with an immersive headgear, people may experience a virtual reality. Second Life already has a Beta version. A number of companies are also working on making more connections through webcams. The idea behind that is the webcam would be watching people and picking up their movements in the real life. If a real-life person waves, the avatar would also be waving. If I smile or wink, my avatar will smile or wink. It would bring in all those non-verbal communication. People are also working on more immersive technology so that if I stand up, my avatar would also stand up. We can also think about applications of these to other fields. People could work on the machines or chemistry or DNA using these multi-dimensional technologies, and we are very close to having them widespread.

Other concerns - In virtual worlds like Second Life, you need to have a high Internet speed to use all the contents. Also, there are areas that you should never take your students to. But if I were to use the Second Life, I would do it this way: If I were to take my students to the New York City, I would need to do my homework. There are great museums in NY, great restaurants. But there could also be a lot of dangerous places that should be watched out for. And Second Life and some other virtual worlds are like that too. If you are working with a younger group of students, you should be avoiding Second Life; instead, have them use Club Penguin owned by Disney, which is very controlled and safe, but very restricted. Teachers would have an ultimate control in terms of choosing the communication setting. 
INTERVIEWER: What do you think about the future of $\mathrm{CMC}$ and what should be done more in order to facilitate the development and application of task-based language learning and teaching with CMC modes? Also, who do you think would benefit the most from TBLT with CMC?

SADLER: To be honest, for me, some people still need to learn how to use these CMC tools and there will, of course, be trials and errors. Teachers like myself and Melinda Dooly, who are using technologies for teaching and learning should be at least familiar with some of the tools. From the teacher perspective, what we need the most is a "site" that helps us to find persons who we could collaborate with. In fact, this has already been started at the site I mentioned earlier: http://uni-collaboration.eu/. For me, it was the case of finding a person to work with - getting the ability to easily find person to work with is a different task especially group-to-group collaborations. If that becomes easy, especially when the communication tools to communicate are built into the site, the development and application of task-based language learning with CMC modes will be greatly facilitated.

For the second part of the question, I think CMC would work well with any age group if you design the lesson right. Potentially, the group that would benefit the most would be the ones that have the least access to a second/foreign language. For those learners, the only chance to communicate with the others in a second/foreign language would be through CMC, and that's a huge benefit.

INTERVIEWER: What kind of tools or things are you covering in the course you have been teaching for about 12 years, Computer Mediated Communication for language learners?

SADLER: That class is kind of like an overview. When I first started teaching the class, I introduced MUD (Multi-User Dungeon), an old text-based interface. The difference now is that there are so many communication tools that are widely used that it becomes possible to learn these tools to communicate with the class on the other side of the world (e.g. Melinda Dooly's class in $\mathrm{UAB}$, Spain) and have students in two classes to learn a variety of tools and then later, collaborate on creating a lesson for their students. Some of the ones we used quite a bit have been message boards, Wikis (which work nicely with asynchronous collaboration), blogs and vlogs, 
and google groups (multi-person video chat for free), which are ideal for a long-distance collaboration. We've also taught students to make and use video podcasts. Most of these are again technologies that are relatively uncomplicated $\mathrm{CMC}$ tools but which provide almost endless opportunities for communication between students. If you are using one of the tools, use it for an authentic purpose and that works better than what you could do in classrooms.

INTERVIEWER: As the Illinois ESL Writing Program Director at the UIUC, what has been some of the innovative approaches that the Program has adopted?

SADLER: When I first started working in the ESL Writing Program at the U of I, there were very good lecturers in the program; however, access to the teaching materials was difficult. When our current lecturer, Susan Faivre came in, she moved all of our TA materials for different levels to blogger sites and this has continued to develop up to now. Each semester, each of our TAs does some kind of project (e.g. creating a lesson or re-writing an existing lesson). What this means is that the available materials are not only getting newer but also becoming better. A lot of teachers have been using blogger, wordpress, Moodle, or compass2g (course-management systems) to archive/share materials as well as to collect assignments from students. Since all our writing classes are done in computer labs, it makes it even more possible to have all the materials online. One of the things people have been using lately is SafeAssign, which is included in the Compass2g site. Now all the students' essays, once uploaded in the compass site, will be automatically checked for any signs of plagiarism based on the database. Students could also use this tool to have feedback on their writing before submitting to the teacher. A team of lecturers including Jin Kim, Hugh Bishop, Jinhee Choo along with others were involved in creating Plagiarism Tutorial Exams where we can teach our students about plagiarism and then give them a test to see they understood it or not. It's especially important for students in our program, because they will be studying in different departments. Overall, we have been using both CMC tools as well as simple technological tools, and they all have been very useful.

INTERVIEWER: Thank you very much! 


\section{References}

Dooly, M., \& Sadler, R. (tbp 2016). Becoming little scientists: A case study of technologicallyenhanced project-based language learning." Language Learning \& Technology.

\section{Websites}

My Language Exchange: http://www.mylanguageexchange.com/

PADS, year 1: http://pagines.uab.cat/pads/en/content/pilot-project-0

PADS, year 2: http://padshealtyhabits.pbworks.com

Unicollaboration: http://uni-collaboration.eu/.

\section{Author information:}

Ha Ram (Hannah) Kim is a PhD student in Linguistics and SLATE (Second Language Acquisition and Teacher Education) at the University of Illinois at Urbana-Champaign where she works as a research assistant for the English Placement Test (EPT). She has also taught academic writing for international students in ESL Writing Program at the same university.

Email: hkim169@illinois.edu

To cite this article:

Kim, H.R. (2015). TBLT meets CMC: Using Virtual Worlds (VWs) in the language learning and teaching. An interview with Dr. Randall Sadler. Bellaterra Journal of Teaching \& Learning Language \& Literature, 8(2), 105116. DOI: http://dx.doi.org/10.5565/rev/jtl3.632 